\title{
The reproductive biology of the Syrian Woodpecker Dendrocopos syriacus in a newly colonized area of south-eastern Poland
}

\author{
Jerzy Michalczuk ${ }^{1} \cdot$ Monika Michalczuk ${ }^{1}$
}

Received: 17 July 2014/Revised: 25 April 2015/Accepted: 29 June 2015/Published online: 21 July 2015

(C) The Author(s) 2015. This article is published with open access at Springerlink.com

\begin{abstract}
In 2003-2006, 73 Syrian Woodpecker nests were studied in a $305-\mathrm{km}^{2}$ area of the agricultural landscape in SE Poland. The median egg-laying date was found to be 12 May and the median fledging date was 20 June (the earliest laying date was April 24 and the latest fledging date was July 25). Females laid from two to seven eggs (median 5.0 eggs, $n=56$ ). An average of 4.4 young hatched per nest $(\mathrm{SD}=1.18$, median 5 , maximum $6, n=41)$ after 9-13 days of incubation (median 10 days, $n=37$ ). Two to six nestlings left successful nests (median 4, $n=37$ ) after 24-30 days (median 27, $n=36$ ), with a mean of $2.8(\mathrm{SD}=2.24$, median $3, n=56)$ young fledging per nest. The main reason for the loss of young observed in $31 \%$ of the Syrian Woodpecker broods was nest parasitism by starlings. These results suggest that the process and dynamics of the range expansion of the Syrian Woodpecker are influenced by a higher reproductive output of Syrian Woodpeckers at the extremities of its range as compared to that of the rest of the Syrian Woodpecker population.
\end{abstract}

Keywords Breeding phenology - Reproductive success · Dendrocopos syriacus

Communicated by O. Krüger.

Jerzy Michalczuk

jurmich@univ.rzeszow.pl

1 Department of Agrobiology and Environmental Protection, University of Rzeszów, Zelwerowicza 4, 35-601 Rzeszów, Poland

\section{Zusammenfassung}

Reproduktionsbiologie des Blutspechts (Dendrocopos syriacus) in einem neu besiedelten Gebiet in SüdostPolen

Zwischen 2003 und 2006 wurden 73 Nester des Blutspechts in einem landwirtschaftlich genutzten Gebiet vom $305 \mathrm{~km}^{2}$ in Südost-Polen untersucht. Der Median des Eiablagedatums war der 12. Mai, der Median des Ausflugdatums der 20. Juni (frühestes Eiablagedatum 24. April; spätestes Ausflugdatum 25. Juli). Die Weibchen legten zwischen 2 und 7 Eiern (Median 5 Eier, $\mathrm{n}=56$ ). Nach 9-13 Tagen Brüten (Median 10 Tage, $\mathrm{n}=37$ ) schlüpften bis zu sechs Jungvögel, mit einem Durchschnitt von 4.4 Jungen pro Nest $(\mathrm{SD}=1.18$, Median $5, \mathrm{n}=41$ ). Nach 24-30 Tagen (Median 27, $\mathrm{n}=36$ ) im Nest, flogen 2 bis 6 Jungtiere aus dem Nest einer erfolgreichen Brut aus (Median 4, n = 37), mit einem Durchschnitt von 2.8 (SD = 2.24, Median 3, $\mathrm{n}=56$ ) insgesamt. Der Hauptgrund für Brutverluste, der bei $31 \%$ der Bruten des Blutspechts gefunden wurde, war Nestparasitismus durch Stare. Die Ergebnisse deuten darauf hin, dass der Prozess und die Dynamik der Ausbreitung des Blutspechts beeinflusst wird durch eine höhere Reproduktionsrate der Population an den äußersten Rändern des Verbreitungsgebiets im Vergleich zur Population im Zentrum.

\section{Introduction}

The Syrian Woodpecker Dendrocopos syriacus has been colonizing Europe since the end of the nineteenth century (Glutz von Blotzheim and Bauer 1980; Cramp 1985), and 
its range currently extends 2 million $\mathrm{km}^{2}$ in central and south-eastern Europe, where its population is estimated to have reached over 200,000-250,000 breeding pairs (BirdLife International 2004). Its colonization of new areas in eastern Europe, where the population is constantly increasing, is proceeding dynamically (Zavialov et al. 2008; Michalczuk 2014). The largest populations of Syrian Woodpecker, comprising over 45,000 breeding pairs each, are found in Turkey, Ukraine, and Bulgaria (BirdLife International 2004). Its range also includes south-eastern Poland, where it has been nesting since 1979 (Ciosek and Tomiałojć 1982). Its population in Poland has now reached 1000-2000 breeding pairs (Michalczuk and Michalczuk 2006a; Michalczuk 2014).

Originally an inhabitant of thermophilic oak forests in Western Asia (Winkler 1973), the Syrian Woodpecker is currently thriving in anthropogenic environments (Shirihai 1996; Mendelssohn and Yom-Tov 1999; Aghanajafizadeh et al. 2011). In Europe, it has also populated woodlots in manmade environments while avoiding dense forests (Glutz von Blotzheim and Bauer 1980; Cramp 1985; Michalczuk and Michalczuk 2011; Ciach and Fröhlich 2013; Fröhlich and Ciach 2013). The Syrian Woodpecker is a monogamous species and, like other European woodpeckers, it produces only one brood per year (Cramp 1985). This species exhibits a high nesting success of 70-90 \% (e.g., Hogstad and Stenberg 1997; Pasinelli 2001; Wiktander et al. 2001; Mazgajski 2002; Kosiński and Ksit 2006; Mazgajski and Rejt 2006). Birds that nest in holes usually successfully reproduce because their broods are difficult for predators to plunder (Martin and Li 1992; Wesołowski and Tomiałojć 2005; Mazgajski and Rejt 2006). However, predators can be the main cause of woodpecker brood loss (Mazgajski 2002; Mazgajski and Rejt 2006; Paclik et al. 2009). Other reasons for unsuccessful woodpecker nesting are nest competition and parasitiism by secondary cavity nesters (Mazgajski 2000, 2003; Kosiński and Ksit 2006). For many woodpecker species, the most significant nest competitor is the Starling Sturnus vulgaris (Ingold 1996; Mazgajski 2003; Koenig 2003; Wiebe 2003). This species exerts strong nest pressure on Syrian Woodpeckers in Europe (Szlivka 1957, 1962; Mitjaj 1986). There are also instances of nest predation in this species in Asia Minor (Al-Safadi 2004). Taking the dynamic spread of the Syrian Woodpecker across Europe into account, it can be assumed that one of the main reasons for its spectacular expansion is reproductive success. Therefore, the aim of the study reported in the present paper was to investigate the breeding biology and reproductive effects of the Syrian Woodpecker in the recently colonized area of SE Poland.

\section{Methods}

\section{Study area}

The study area $\left(305 \mathrm{~km}^{2}\right)$ was inhabited by 30 breeding Syrian Woodpecker pairs in 2003, but this number had increased to 50 by 2006 (Michalczuk and Michalczuk 2006a; own observations). The area is located in the southeastern part of Poland $\left(50^{\circ} 28^{\prime} \mathrm{N}, 23^{\circ} 40^{\prime} \mathrm{E}\right)$ and is characterized by gentle hills that are 195-263 m above sea level (Kondracki 2000). Crop fields predominate, comprising $71 \%$ of the area. The marshy valleys found in the study area have meadows that cover $11 \%$ of the area, while small forests extend across only $4 \%$ of the area. The forests in the eastern part of the study area are dominated by broadleaved trees, a substantial proportion of which are Common Hornbeam Carpinus betulus and oaks Quercus spp., whereas the western part is dominated by evergreen forests with a distinct predominance of Scots Pine Pinus sylvestris. Tree cover in built-up areas (human settlements) makes up $14 \%$ of the study area. These tree stands are mostly groups of trees dominated by willows Salix spp., poplars Populus spp., and ash trees Fraxinus spp. However, fruit trees are encountered just as often, including Apple Malus domestica, Sour Cherry Prunus cerasus, and plum trees Prunus spp., as well as Walnut Juglans regia. Roadsides and lanes, as well as the few parks and cemeteries in the study area, mostly contain ash trees Fraxinus spp., maples Acer spp., and poplars Populus spp. Conifers such as spruces Picea spp., larches Larix spp., and pines Pinus spp. are only rarely found in anthropogenic stands in the built-up areas. The climate of this area is transitional with many continental characteristics. Annual rainfall is $600-700 \mathrm{~mm}$, and the average temperature is about $7.5^{\circ} \mathrm{C}$ (Woś 1999).

\section{Identifying territories and nest visits}

Syrian Woodpecker territories were detected using a mapping method together with playback (for details see Michalczuk and Michalczuk 2006a, b; Michalczuk et al. 2011). Bird searches were conducted mainly in March and April in 2003-2006 in anthropogenic stands, which are preferred by this species (Glutz von Blotzheim and Bauer 1980; Cramp 1985). In our field work we mainly monitored villages; "stimulation points" (see below) were established every $200-400 \mathrm{~m}$ on the streets of these villages. We also checked various tree groups and woods located in fields and meadows and at the edges of forests. At the stimulation points mentioned above, a sequence of Syrian Woodpecker calls and drumming was played for 5 min unless woodpeckers were spotted during the sequence, in which case it 
was immediately stopped. When woodpeckers were not observed during playback, we monitored the tree cover near the stimulation point for about $1 \mathrm{~min}$, looking for unresponsive woodpeckers. The location and behavior of each woodpecker encountered were marked on a 1:25,000scale map. We then moved by road to the next point on foot or by car, where the stimulation and bird search was continued (Michalczuk and Michalczuk 2006a, b; Michalczuk et al. 2011). To make it easier to distinguish between neighboring individuals and pairs, five females and six males from seven territories were color-ringed in 2002-2004. In each breeding season during 2003-2006, at least six searches were performed in the study area. A breeding territory was defined as a region where there had been at least three confirmed sightings of woodpeckers (Michalczuk and Michalczuk 2006a, b; Michalczuk et al. 2011).

In territories detected in this way, we then searched for Syrian Woodpecker nests. The nest cavities found were monitored from mid-April to July, and their contents were checked every day using a small mirror and a source of light to illuminate the nest cavity in the tree hole. Nests were monitored every 2-3 days from the start of the incubation period. During this brood stage, observations were performed every day close to the nest trees to check whether the number of birds in the nest changed or the brood was abandoned. After 8 days of incubation (counted from the last laying day), the nests were checked every day to determine the exact hatching date and number of chicks. Five-day-old nestlings were monitored every 2-3 days, but after 20 days the nests were checked every day again to determine the exact fledging date. In this way, we were able to determine the egg-laying (only broods at the egglaying stage were used in the analysis) and hatching dates, the size of the clutch, the number of nestlings, and the fledging date. After the nestlings had fledged, the nest hole was examined to determine if it contained any eggs or dead chicks. A total of 73 Syrian Woodpecker nests were studied. All but one of the broods considered were located in newly excavated holes.

\section{Assessment of breeding parameters}

Only nests that were at the egg-laying or incubation stage when found were used to assess reproductive parameters. Nesting success was calculated as the ratio of the number of nests with at least one fledged young to the number of nests in which eggs were found. Hatching success was calculated as the percentage of the monitored eggs from which nestlings hatched, and breeding success was considered to be the percentage of the monitored eggs that resulted in fledged young. For both of these indices, we only included nests in which the female completed her egg laying; that is, nests in which no further eggs were added after two consecutive days. Nests that were observed to have been destroyed or abandoned during egg laying (e.g., as a result of nest parasitism by starlings) were treated as incomplete clutches. Such data were only used to assess the phenology of the breeding attempts of this species and to calculate its nesting success. The length of the breeding period in different seasons was calculated from the day on which the first egg was laid in the earliest nest to the day on which the last nestling fledged. The incubation period was calculated for individual nests as the day on which the last egg was laid to the day before the first nestling hatched. The length of stay of the nestlings in the nest was measured from the date on which the first young hatched to the day on which the first nestling fledged from the nest cavity. The durations of specific breeding stages were compared to the number of days from April 1 to the day on which the next breeding stage began (egg laying, hatching, or fledging). One day was added during 2004, as it it was a leap year (see Table 1). Relative dates of specific breeding stages were set relative to the medians calculated for the breeding stages in a given breeding season. Based on direct observations of nests and traces and remnants of birds or eggs left in or near the nest cavity, the degree of nest loss (as a result of, e.g., nest parasitism by other hole-nesting species) was assessed.

\section{Statistical analysis}

Statistical calculations were performed using the Statistica Soft 7.1 Pl software. A significance level of 0.05 was employed for all statistical differences. The KruskalWallis test along with the Dunn post hoc test were used in the statistical analysis. The relationships between qualitative variables were analyzed using the chi-square test, and Spearman's rank correlation coefficient was used when investigating relationships between quantitative variables.

\section{Results}

\section{Egg-laying phenology}

The Syrian Woodpeckers began nesting at some point during the period from April 24 to May 3 (Table 1). The average egg-laying date was May 15, and even though this ranged from May 10 to 18 depending on the year, no statistical differences in average egg-laying date were found among years $(H=2.97, d f=3$, ns, Table 1$)$. Some egg laying occurred in April (8.8\% of nests) during the 2004 and 2005 seasons, but not in the others. However, $80.7 \%$ of the Syrian Woodpecker females laid their first egg in 
Table 1 Breeding phenology and parameters of the Syrian Woodpeckers observed in 2003-2006

\begin{tabular}{|c|c|c|c|c|c|}
\hline \multirow[t]{2}{*}{ Breeding parameter } & \multicolumn{4}{|l|}{ Year } & \multirow[t]{2}{*}{ Total } \\
\hline & 2003 & 2004 & 2005 & 2006 & \\
\hline \multicolumn{6}{|l|}{ Laying date* } \\
\hline Mean \pm SD & $48 \pm 11.3$ & $41 \pm 10.8$ & $48 \pm 16.8$ & $43 \pm 10.9$ & $45 \pm 12.2$ \\
\hline Range & $33-66$ & $25-59$ & $24-75$ & $31-76$ & $24-76$ \\
\hline Date & $3 \mathrm{~V}-5 \mathrm{VI}$ & $24 \mathrm{IV}-28 \mathrm{~V}$ & $24 \mathrm{IV}-14 \mathrm{VI}$ & $1 \mathrm{~V}-15 \mathrm{VI}$ & $24 \mathrm{IV}-15 \mathrm{VI}$ \\
\hline$n$ (median) & $14(46.0)$ & $12(42.5)$ & $10(47.5)$ & $21(41.0)$ & $57(43.0)$ \\
\hline \multicolumn{6}{|l|}{ Hatching date* } \\
\hline Mean \pm SD & $64 \pm 12.0$ & $56 \pm 10.9$ & $61 \pm 13.4$ & $58 \pm 9.9$ & $61 \pm 12.3$ \\
\hline Range & $48-80$ & $41-72$ & $41-88$ & $46-76$ & $41-88$ \\
\hline Date & $18 \mathrm{~V}-19 \mathrm{VI}$ & $10 \mathrm{~V}-10 \mathrm{VI}$ & $11 \mathrm{~V}-27 \mathrm{VI}$ & $16 \mathrm{~V}-15 \mathrm{VI}$ & $10 \mathrm{~V}-27 \mathrm{VI}$ \\
\hline$n$ (median) & $13(63.0)$ & $8(57.5)$ & $10(59.5)$ & $12(56.0)$ & $43(58.0)$ \\
\hline \multicolumn{6}{|l|}{ Fledging date* } \\
\hline Mean \pm SD & $83 \pm 10.3$ & $83 \pm 10.7$ & $87 \pm 12.9$ & $87 \pm 12.1$ & $86 \pm 12.0$ \\
\hline Range & $73-105$ & $67-97$ & $74-113$ & $74-109$ & $67-113$ \\
\hline Date & $12 \mathrm{VI}-14 \mathrm{VII}$ & $5 \mathrm{VI}-5 \mathrm{VII}$ & $13 \mathrm{VI}-22 \mathrm{VII}$ & $13 \mathrm{VI}-18 \mathrm{VII}$ & $5 \mathrm{VI}-22 \mathrm{VII}$ \\
\hline$n$ (median) & $16(78.5)$ & $9(82.5)$ & $10(84.0)$ & $11(83.0)$ & $46(83.0)$ \\
\hline \multicolumn{6}{|c|}{ Duration of breeding season } \\
\hline Date & $3 \mathrm{~V}-17 \mathrm{VII}$ & 24 IV-6 VII & $24 \mathrm{IV}-25 \mathrm{VII}$ & $1 \mathrm{~V}-19 \mathrm{VII}$ & $24 \mathrm{IV}-25 \mathrm{VII}$ \\
\hline$n$ days & -75 & -74 & -93 & -80 & $(74-93)$ \\
\hline \multicolumn{6}{|l|}{ Clutch size } \\
\hline Mean \pm SD & $5.0 \pm 0.85$ & $5.0 \pm 1.04$ & $5.1 \pm 1.38$ & $5.1 \pm 0.68$ & $5.0 \pm 0.99$ \\
\hline Range & $4-6$ & $3-6$ & $2-7$ & $3-7$ & $2-7$ \\
\hline$n$ (median) & $15(5.0)$ & $12(5.0)$ & $12(5.5)$ & $17(5.0)$ & $56(5.0)$ \\
\hline \multicolumn{6}{|c|}{ Number of hatched nestlings } \\
\hline Mean \pm SD & $4.0 \pm 1.35$ & $4.5 \pm 0.93$ & $4.4 \pm 1.51$ & $4.9 \pm 0.70$ & $4.4 \pm 1.18$ \\
\hline Range & $2-6$ & $3-6$ & $1-6$ & $4-6$ & $1-6$ \\
\hline$n$ (median) & $13(4.0)$ & $8(4.5)$ & $9(5.0)$ & $11(5.0)$ & $41(5.0)$ \\
\hline \multicolumn{6}{|c|}{ Number of fledglings in a successful nest } \\
\hline Mean \pm SD & $4.1 \pm 1.38$ & $4.1 \pm 1.21$ & $4.6 \pm 1.27$ & $4.2 \pm 1.08$ & $4.2 \pm 1.20$ \\
\hline Range & $2-6$ & $2-5$ & $3-6$ & $2-6$ & $2-6$ \\
\hline$n$ (median) & $12(4.0)$ & $7(5.0)$ & $7(5.0)$ & $11(4.0)$ & $37(4.0)$ \\
\hline \multicolumn{6}{|c|}{ Number of fledglings in a failed brood } \\
\hline Mean \pm SD & $3.3 \pm 2.09$ & $2.4 \pm 2.31$ & $2.7 \pm 2.53$ & $2.8 \pm 2.23$ & $2.8 \pm 2.24$ \\
\hline Range & $0-6$ & $0-5$ & $0-6$ & $0-6$ & $0-6$ \\
\hline$n$ (median) & $15(4.0)$ & $12(2.5)$ & $12(3.0)$ & $17(4.0)$ & $56(3.0)$ \\
\hline \multicolumn{6}{|c|}{ Incubation phase (days) } \\
\hline Mean \pm SD & $9.7 \pm 0.65$ & $10.3 \pm 0.82$ & $10.8 \pm 1.28$ & $10.3 \pm 0.75$ & $10.2 \pm 0.92$ \\
\hline Range & $9-11$ & $9-11$ & $9-13$ & $9-11$ & $9-13$ \\
\hline$n$ (median) & $11(11.0)$ & $6(10.5)$ & $8(10.5)$ & $12(10.0)$ & $37(10.0)$ \\
\hline \multicolumn{6}{|l|}{ Nestling phase (days) } \\
\hline Mean \pm SD & $26.8 \pm 1.34$ & $27.7 \pm 1.25$ & $26.9 \pm 1.46$ & $27.4 \pm 0.70$ & $27.2 \pm 1.21$ \\
\hline Range & $24-29$ & $26-30$ & $25-29$ & $26-28$ & $24-30$ \\
\hline$n$ (median) & $12(27)$ & $7(28)$ & $7(26)$ & $10(27.5)$ & $36(27)$ \\
\hline \multicolumn{6}{|l|}{ Hatching success } \\
\hline$\%$ & 69.3 & 60 & 70.5 & 66.3 & 66.7 \\
\hline$n$ eggs & 75 & 60 & 61 & 86 & 282 \\
\hline$n$ broods & (15) & (12) & (12) & (17) & $(56)$ \\
\hline \multicolumn{6}{|l|}{ Breeding success } \\
\hline$\%$ & 65.3 & 51.7 & 55.7 & 51.2 & 56 \\
\hline
\end{tabular}


Table 1 continued

\begin{tabular}{llllll}
\hline Breeding parameter & \multicolumn{2}{l}{ Year } & & Total \\
\cline { 2 - 5 } & 2003 & 2004 & 2005 & 2006 & \\
\hline$n$ eggs & 75 & 60 & 61 & 86 & 282 \\
$n$ broods & $(15)$ & $(12)$ & $(12)$ & $(17)$ & $(56)$ \\
Nesting success & & & & 50 & 56.9 \\
$\%$ & 70.6 & 50 & 58.3 & 50 \\
$n$ broods & $(17)$ & $(14)$ & $(12)$ & $(22)$ & $(65)$ \\
\hline
\end{tabular}

None of the breeding parameters showed any between-year differences (statistical tests employed are discussed in the text); * days from 1 April, except during 2004 (a leap year), when 1 day was added

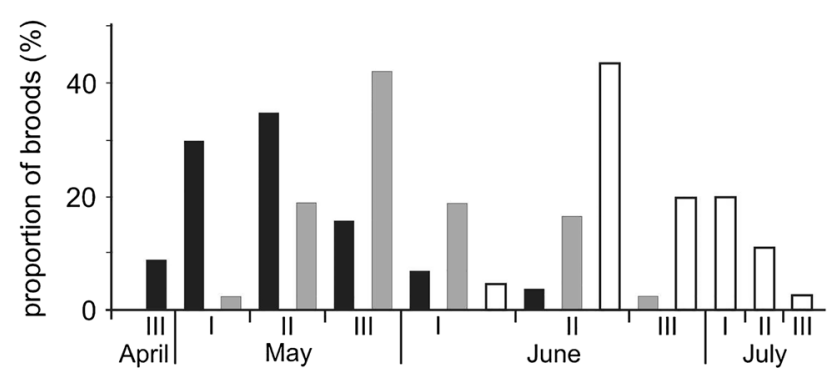

Fig. 1 Syrian Woodpecker breeding phenology for specific 10-day periods during the breeding season. Black day on which the first egg of the clutch was laid $(n=57)$, gray day on which the first young of the brood hatched $(n=43)$, white day on which the first young of the brood fledged $(n=37)$

May (Fig. 1). The last egg laying occurred on June 14 in 2005 and June 15 in 2006.

\section{Size of clutch}

Females laid one egg each day, apart from an exceptional one-day break in egg laying that was observed in 2003. The clutch size ranged from two (observed for just one clutch) to seven eggs, with an average of five eggs (39.3\%, $n=56$ ), and there was no between-year difference in this mean $(H=0.333, d f=3$, ns, Table 1). Clutch size decreased as the season progressed ( $\mathrm{rs}=-0.55, n=51$, $p<0.05$, Fig. 3).

\section{Incubation and hatching}

The incubation period for Syrian woodpecker eggs ranged from 9 to 13 days, with hatching most often occurring after 10 days ( $45.9 \%$ of broods, $n=37$ ). Incubation periods lasting 9 and 11 days were also often observed (21.6 and $27.0 \%$, respectively). Only in one case each $(2.7 \%)$ did nestlings hatch after 12 or 13 days of incubation. The median length of the incubation period was 10 days, and there was no between-year difference in this median length $(H=5.30 ; d f=3 ; \mathrm{ns}$, Table 1). The earliest and latest hatching dates observed were May 10 and June 27. The mean hatching date was May 31, and this did not differ statistically significantly among years $(H=1.74 ; d f=3$; ns, Table 1). Hatching most often occurred during the last ten days of May, when $41.9 \%$ of the clutches hatched (Fig. 1).

Most often, five young hatched in a clutch $(36.5 \%$, $n=41)$. Four and six young hatched less often (29.3 and $17.1 \%$ respectively, Fig. 2). There was no statistically significant difference among years in the mean of the number of young that hatched $(H=3.34 ; d f=3$; ns), and the long-term mean hatching rate of young was 4.4 (range 4.0-4.9) during the years of the study (Table 1).

\section{Nest occupation}

The young remained in the nest for an average of 27 days; there was no statistically significant difference among years in this average $(H=3.20 ; d f=3 ; \mathrm{ns}, n=36$, Table 1). The young remained in $33.3 \%$ of the nests for 27 days, in $22.2 \%$ of the nests for 26 days, and in $27.8 \%$ of the nests for 28 days. There were only three cases of birds remaining in the nest for 29 days $(8.3 \%)$, and only once did this period last for 24,25 , or 30 days (each representing $2.8 \%$, Table 1 ).

The earliest that young left the nest was 5 June, and the latest was 22 July. The length of the breeding season ranged from 74 to 93 days (Table 1). The largest proportion of the young $(43.5 \%)$ fledged in mid-June; $19.6 \%$ of the broods fledged at the end of June, and another $19.6 \%$ during the first 10 days of July (Fig. 1). There was no statistically significant difference among years in the mean

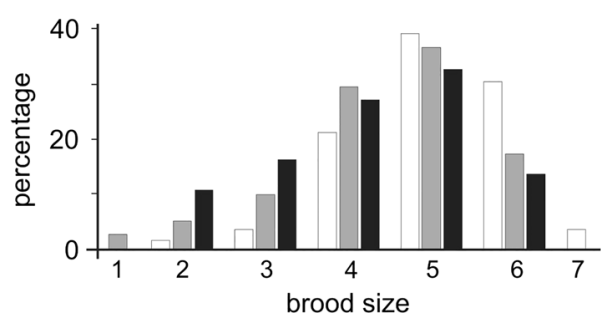

Fig. 2 Distribution of Syrian woodpecker brood sizes in 2003-2006. White size of clutch $(n=56)$, gray number of hatched nestlings $(n=41)$, black number of fledglings $(n=37)$ 


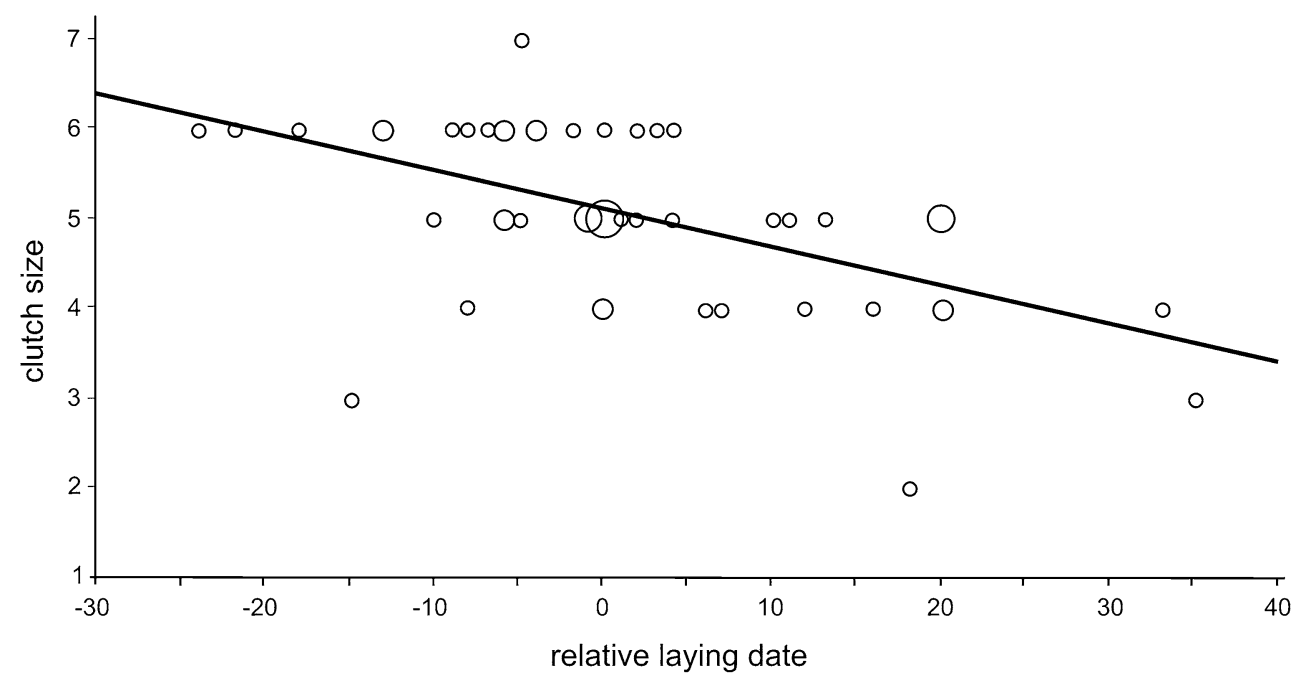

Fig. 3 Clutch size versus relative date on which the first egg was laid, calculated based on the median number of eggs laid in each breeding season (the size of the circle for each data point represents the corresponding $n$ value, which ranges from 1 to 4 , and total $n=51$ )

date on which the young left the nest hole $(H=0.77$; $d f=3$; ns, $n=46)$. This date ranged between June 22 and 26 , with the average falling on June 25 (Table 1).

\section{Size of brood}

From two to six nestlings fledged; five fledged in $32.5 \%$ of the broods ( $n=37$ ) (Fig. 2), and two fledged in just four nests $(10.8 \%)$. As the breeding season progressed, fewer young fledged ( $\mathrm{rs}=-0.49, P<0.05, n=46$, Fig. 4 ). The mean number of fledged young did not differ statistically significantly among seasons $(H=0.70 ; d f=3 ; \mathrm{ns}, n=37$, Table 1). When all of the clutches (together with losses) were considered, the mean number of fledglings was 2.8, and the number of fledgings ranged from 2.4 to 3.3 young per pair $(H=0.88 ; d f=3$; ns, $n=56)$. When only

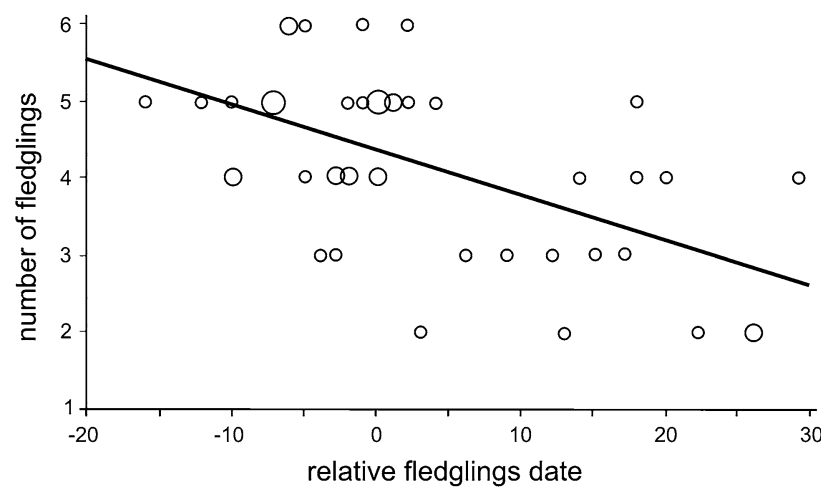

Fig. 4 Correlation between the number of young leaving the nest and the relative date of fledging. Calculated for the median date of fledging during each breeding season (the size of the circle for each data point represents the corresponding $n$ value, which ranges from 1 to 3 , and total $n=46$ ) successful nests were considered, the mean was 4.2 fledglings and the range was $4.1-4.6$ young per pair (Table 1 ).

\section{Causes and extent of nest loss}

Syrian Woodpecker hatching success ranged from 60.0 to $70.5 \%$ and was not statistically significantly different among seasons $\left(\right.$ mean $66.7 \% ; \chi^{2}$ test $=1.49 ; d f=3$; ns, Table 1). The breeding success ranged from 51.2 to $65.3 \%$. The average was $56.0 \%$, and there was no statistically significant difference in the average among the study years $\left(\chi^{2}\right.$ test $=3.93 ; d f=3$; ns). Nesting success averaged $56.9 \%$ and showed no between-year differences ( $\chi^{2}$ test $=2.20 ; d f=3$; ns). The proportion of the monitored nests in which at least one nestling fledged ranged from 50.0 to $70.6 \%$ (Table 1).

There was no confirmed Syrian Woodpecker nest predation; instead, Starlings Sturnus vulgaris caused the greatest number of losses. This species is the main parasite of Syrian Woodpecker nests, destroying 23.5-40.9\% (mean $30.8 \%, n=65)$ of them. Some losses (6.2\%) also resulted from the clutch becoming cold; others $(1.5 \%$ each, $n=65$ ) were caused by hypothermia in the chicks, flooding caused by tree sap, nest parasitism by the Wryneck Jynx torquilla, or brood abandonment.

\section{Discussion}

\section{Breeding phenology}

The date of the start of the breeding period of the studied population of Syrian Woodpeckers was similar to that of 
the population of Syrian Woodpeckers in Ukraine (Afanasyev 1998). This was 1-2 weeks later than those of the populations in Austria, Vojvodina, and Israel, where the species starts laying eggs in mid-April (Szlivka 1957, 1962; Ruge 1969; Barnea 1982; Shirihai 1996; MerstenKatz et al. 2012). Indeed, the beginning of the breeding season occurs in the last week of April and the beginning of May in the Gaza Strip (Al-Safadi 2004), although only five broods of Syrian Woodpecker were investigated in that work, which may be an incomplete picture of the reproductive phenology of this species in that area. It can be assumed that breeding begins a little later at higher latitudes than in southern regions (e.g., Sanz 1998). This suggests that the variation in the beginning of the breeding season may be due to the slower growth of vegetation in cooler climates and the subsequent shift in the emergence of insects, which are the primary food of woodpecker nestlings (Glutz von Blotzheim and Bauer 1980; Cramp 1985). For this reason, a characteristic shift in breeding period is observed in birds that attempt to adapt their breeding periods to the period of optimal food resources in the environment (Lack 1954).

The length of the egg-incubation period for the Syrian Woodpecker study population was similar to the corresponding length for populations in other, warmer regions of the range of this species: it averaged 11 days and ranged from 9 to 14 days (Ruge 1969; Marisova and Butenko 1976; Barnea 1982; Cramp 1985; Mersten-Katz et al. 2012). The time that young Syrian Woodpeckers in the study population spent in the nest was quite similar to the corresponding time recorded for the Austrian population, where it was about 24-26 days (Ruge 1969; Holzer and Holzer 1982). Young were found to occupy nests for very short periods in Vojvodina: 21 or sometimes just 17 days (Szlivka 1957). In this case, one factor that likely accelerated the departure of young was nest disturbance by the author (Szlivka 1957; 1962; Ruge 1969). This appears to be confirmed by the results obtained in warmer regions, such as Israel and the Gaza Strip, where young leave the nest well after 26 days (Barnea 1982; Al-Safadi 2004; MerstenKatz et al. 2012).

\section{Factors influencing the clutch size}

The clutch size in the Syrian Woodpecker study population was similar to those in the Austrian and Romanian populations. In those countries, the average was 5.1-5.2 eggs, and the range was 4-7 eggs (Ruge 1969; Glutz von Blotzheim and Bauer 1980). Further south in Vojvodina, Israel, and the Gaza Strip, clutches were smaller, with some comprising 3-7 eggs (Szlivka 1957; Barnea 1982; Shirihai 1996; Al-Safadi 2004). Much larger clutches were recorded in the northern part of the woodpecker's geographical range. Clutches of 3-12 eggs were found in Ukraine, where 8-9 eggs were most often noted (Marisova and Butenko 1976; Afanasyev 1998). Similarly sized clutches were observed for the subspecies $D$. s. transcaucasicus, which inhabits the Caucasus, where up to 11 eggs per clutch were observed (Dementiev et al. 1951). Looking at the locations from which the cited data were obtained, it can be assumed that the brood size varies in order to optimize the reproductive success of the Syrian Woodpecker at different latitudes. In northern regions, where the day is longer, birds may invest in larger broods because they can spend much longer hunting for food than in southern areas, thus allowing them to feed more young (Lack 1954; Sanz 1998).

Differences in clutch size may also derive from variations in the Syrian Woodpecker density in different areas. It has been found that clutches are larger when there is less intraspecies competition among birds (Nummi and Saari 2003). Such a dependency can also be discerned in the Syrian Woodpecker population. In the study area, where the species reaches a density of approximately 14-20 pairs/ $10 \mathrm{~km}^{2}$ in optimal habitats (Michalczuk and Michalczuk 2006a), females lay more eggs than in Israel, where the population density reaches over 40 pairs $/ 10 \mathrm{~km}^{2}$ (Shirihai 1996). In that region, the Syrian woodpecker clutch size is the smallest, ranging from three to five eggs (Barnea 1982; Shirihai 1996; Al-Safadi 2004). In the north-eastern part of the species' range (i.e., Ukraine), where the woodpecker density is several times smaller (approximately 0.5-5.0 pairs $/ 10 \mathrm{~km}^{2}$; Mitjaj 1986), the clutch size is much larger, most commonly 8-9 eggs (Afanasyev 1998). These differences suggest that northern populations may have a greater reproductive rate than central populations, which may in turn increase the sizes of the populations found at range extremities. This may be confirmed by the increased expansion of the species in Russia, at the northeastern extremity of the Syrian Woodpecker's range (Zavialov et al. 2008).

The average number of young leaving the nest from successful broods in the Syrian Woodpecker study population was higher than that in the Vojvodina population, where it was 3.4 young (Szlivka 1962). The corresponding result for the Austrian population, approximately 4.5 young (Ruge 1969), suggests that such diverse reproductive rates are probably due to differences in the clutch size of this species among the regions mentioned.

\section{Reproductive success}

The nesting success of the Syrian Woodpecker study population was slightly lower than those observed for other primary cavity nesters, such as the Greater Spotted and Middle Spotted Woodpeckers, which have average nesting 
successes of 70-80 \% (Pasinelli 2001; Mazgajski 2002; Kosiński and Ksit 2006). The hatching success of the Syrian Woodpeckers in our study area was similar to those of the Austrian population (72\%; Ruge 1969) and the Middle Eastern population (58 \%; Al-Safadi 2004). However, the breeding success in the latter region was significantly lower, $38 \%$ (Al-Safadi 2004). This reproductive rate is approximately half that seen in our study, and is the result of nest predation by snakes or rats, which leads to a loss of about $40 \%$ of the broods in the Middle East (AlSafadi 2004). This may also be a reason why woodpeckers in the Middle East lay fewer eggs - to enable re-nesting after an initial failed attempt (e.g., Slagsvold 1982).

Results obtained from other regions such as Vojvodina and Ukraine (Szlivka 1957, 1962; Ruge 1969; Marisova and Butenko 1976; Afanasyev 1998) confirm that there are no predator-related losses of European Syrian Woodpecker broods. Those observations indicate that the level of nest predation experienced by this species may depend on geographical location and may also be modified by the type of environment in which the birds nest (e.g., Thorington and Bowman 2003; Jokimäki et al. 2005). This is because this species colonizes a variety of very different habitats (Mendelssohn and Yom-Tov 1999; Aghanajafizadeh et al. 2011; Michalczuk and Michalczuk 2011; Fröhlich and Ciach 2013). Our research indicates that the Syrian Woodpecker has circumvented the threat posed by nest predators by colonizing anthropogenic habitats in Europe. This most likely increases breeding success and favors the growth of the European population of this species. However, as demonstrated by our research and confirmed in the literature (Szlivka 1957, 1962; Mitjaj 1986; Michalczuk et al. 2011), the reproductive success of European populations of the Syrian Woodpecker is lowered by the significant nest parasitism performed by the Starling, which destroys about one-third of the Syrian Woodpecker broods in Europe. Such considerable pressure from this secondary cavity nester can weaken the pace of expansion and inhibit the colonization of new areas by the Syrian Woodpecker.

Open Access This article is distributed under the terms of the Creative Commons Attribution 4.0 International License (http://crea tivecommons.org/licenses/by/4.0/), which permits unrestricted use, distribution, and reproduction in any medium, provided you give appropriate credit to the original author(s) and the source, provide a link to the Creative Commons license, and indicate if changes were made.

\section{References}

Afanasyev VT (1998) Sirijskij djatel v Sumskom Polesie. In: Materials of the Third Conference of Young Ornithologists of Ukraine, Chernivtsy, Ukraine, 1998

Aghanajafizadeh A, Heydari F, Naderi G, Hemami MR (2011) Nesting hole site selection by the Syrian woodpecker,
Dendrocopos syriacus, in Yazad Province, Iran. Zool Middle East 53:3-6

Al-Safadi MM (2004) On the breeding biology of the Syrian woodpecker, Dendrocopos syriacus, in the Gaza Strip. Zool Middle East 32:7-12

Barnea A (1982) On the biology of the Syrian woodpecker (Dendrocopos syriacus) in Israel. M.Sc. thesis. Tel Aviv University, Tel Aviv

BirdLife International (2004) Birds in Europe: population estimates, trends and conservation status. Conservation Series No. 12. BirdLife International, Cambridge

Ciach M, Fröhlich A (2013) Habitat preferences of the Syrian woodpecker Dendrocopos syriacus in urban environments: an ambiguous effect of pollution. Bird Study 60:491-499

Ciosek J, Tomiałojć L (1982) Dzięcioł syryjski, Dendrocopos syriacus (Hempr. et Ehrenb.), ptakiem lęgowym w Polsce. Prz Zool 26:101-109

Cramp S (ed) (1985) The birds of the western palearctic, vol 4. Oxford University Press, Oxford

Dementiev GP, Gladkov NA, Ptuszenko ES, Spangenerg EP, Sudilovskaja AM (eds) (1951) Pticy Sovietskogo Sojuza. Gosud. Izdat. Sovietskaja Nauka, Moskva

Fröhlich A, Ciach M (2013) Rozmieszczenie i liczebność dzięcioła białoszyjego Dendrocopos syriacus w Krakowie. Ornis Pol $54: 237-246$

Glutz von Blotzheim UN, Bauer K (eds) (1980) Handbuch der Vögel Mitteleuropas, vol 9. Akademische Verlag, Wiesbaden

Hogstad O, Stenberg I (1997) Breeding success, nestling diet and parental care in the white-backed woodpecker Dendrocopos leucotos. J Ornithol 138:25-38

Holzer G, Holzer G (1982) Erstnachweis der Brut des Blutspechtes (Dendrocopos syriacus) für Oberösterreich im Stadtgebiet von Linz. Öko-L 4:18-22

Ingold DJ (1996) Delayed nesting decreases reproductive success in northern flickers: implications for competition with European starlings. J Field Ornithol 67:321-326

Jokimäki J, Kaisanlahti Jokimäki ML, Sorace A, Fernández-Juricic E, Rodriguez-Prieto I, Jimenez MD (2005) Evaluation of the "safe nesting zone" hypothesis across an urban gradient: a multi-scale study. Ecography 28:59-70

Koenig WD (2003) European starlings and their effect on native cavity-nesting birds. Conserv Biol 17:1134-1140

Kondracki J (2000) Geografia regionalna polski. Wyd Naukowe PWN, Warszawa

Kosiński Z, Ksit P (2006) Comparative reproductive biology of middle spotted woodpeckers Dendrocopos medius and great spotted woodpeckers D. major in a riverine forest. Bird Study 53:237-246

Lack D (1954) The natural regulation of animal numbers. Oxford, London

Marisova IV, Butenko AG (1976) Materialy k rasprostraneniju i ekologii sirijskovo djatla (Dendrocopos syriacus) na Ukrainie. Vestnik Zoologii 2:29-34

Martin TE, Li P (1992) Life history traits of open- vs. cavity-nesting birds. Ecology 73:579-592

Mazgajski TD (2000) Competition for nest sites between the Starling Sturnus vulgaris and other cavity nesters-study in forest park. Acta Ornithol 35:103-107

Mazgajski TD (2002) Nesting phenology and breeding success in great spotted woodpecker Picoides major near Warsaw (Central Poland). Acta Ornithol 37:1-5

Mazgajski TD (2003) Nesting interaction between woodpeckers and starlings-delayed commensalism, competition for nest sites or cavity kleptoparasitism? In: Pechacek P, D’Oleire-Oltmanns W (eds) Proceedings of the International Woodpecker Symposium. Forschungsbericht 48. Nationalparkverwaldung, Berchtesgaden, pp 133-138 
Mazgajski T, Rejt $Ł$ (2006) The effect of forest patch size on the breeding biology of the great spotted woodpecker Denrocopos major. Ann Zool Fenn 43:211-220

Mendelssohn H, Yom-Tov Y (1999) A report of birds and mammals which have increased their distribution and abundance in Israel due to human activity. Isr J Zool 45:35-47

Mersten-Katz C, Barnea A, Yom-Tov Y, Ar A (2012) The woodpecker's cavity microenvironment: advantageous or restricting? Avian Biol Res 5:227-237

Michalczuk J (2014) Expansion of the Syrian woodpecker Dendrocopos syriacus in Europe and Western Asia. Ornis Polonica 55:149-161

Michalczuk J, Michalczuk M (2006a) Reaction on playback and density estimations of Syrian woodpecker Dendrocopos syriacus in agricultural areas of SE Poland. Acta Ornithol 41:33-39

Michalczuk J, Michalczuk M (2006b) Przydatność metody kartograficznej z użyciem stymulacji głosowej do oceny liczebności dzięcioła białoszyjego Dendrocopos syriacus. Notatki Ornitologiczne 47:175-184

Michalczuk J, Michalczuk M (2011) Dzięcioł białoszyi Dendrocopos syriacus w Zlewni Górnej Huczwy w latach 2004-2006. Chrońmy Przyrodę Ojczystą 67:426-432

Michalczuk J, Michalczuk M, Cymbała R (2011) Przydatność różnych metod do monitoringu liczebności dzięcioła białoszyjego Dendrocopos syriacus. Ornis Polonica 52:280-287

Mitjaj IS (1986) Sirijskij djatel v Pridneprovskoj lesostepi. Rzucenie ptic SSSR, ich ochrana i racionalnoe ispolzovanie. Wyd. Akademija Nauk SSSR, Leningrad, pp 70-71

Nummi P, Saari L (2003) Density-dependent decline of breeding success in an introduced, increasing mute swan Cygnus olor population. J Avian Biol 34:105-111

Paclik M, Misik J, Weidinger K (2009) Nest predation and nest defence in European and North American woodpeckers: a review. Ann Zool Fenn 46:361-379
Pasinelli G (2001) Breeding performance of the middle spotted woodpecker Dendrocopos medius in relation to weather and territory quality. Ardea 89:353-361

Ruge K (1969) Beobachtungen am Blutspecht Dendrocopos syriacus im Burgenland. Vogelwelt 90:201-223

Sanz JJ (1998) Effects of geographic location and habitat on breeding parameters of great tits. Auk 115:1034-1051

Shirihai H (1996) The birds of Israel. Academic, London

Slagsvold T (1982) Clutch size variation in passerine birds: the nest predation hypothesis. Oecologia 54:159-169

Szlivka L (1957) Von der Biologie des Blutspechts Dendrocopos syriacus balcanicus, und seinen Beziehungen zu den Staren, Sturnus vulgaris. Larus 9(10):48-70

Szlivka L (1962) Weitere Angaben über den Blutspecht aus der näheren Umgebung von Gunaroš. Larus 14:121-134

Thorington KK, Bowman R (2003) Predation rate on artificial nests increases with human housing density in suburban habitats. Ecography 26:188-196

Wesołowski T, Tomiałojć L (2005) Nest sites, nest depredation, and productivity of avian broods in a primeval temperate forest: do the generalisations hold? J Avian Biol 36:361-367

Wiebe KL (2003) Delayed timing as a strategy to avoid nest-site competition: testing a model using data from starlings and flickers. Oikos 100:291-298

Wiktander U, Olsson O, Nilsson SG (2001) Annual and seasonal reproductive trends in the lesser spotted woodpecker Dendrocopos minor. Ibis 143:72-82

Winkler H (1973) Nahrungserwerb und Konkurrenz des Blutspechts Picoides (Dendrocopos) syriacus. Oecologia 12:193-208

Woś A (1999) Klimat Polski. Wyd Naukowe PWN, Warszawa

Zavialov E, Tabachishin VG, Mosolova EY (2008) Expansion of Syrian woodpecker in European Russia and Ukraine. Dutch Bird 30:236-238 